\title{
Perception and changes for E-banking among young people in the country - the period of the Corona crisis
}

ISSN 1857-9973

UDC 336.71:004.031.4]-053.6(497.4)

336.71:004.031.4]-053.6(497.7)

\section{Marija Gogova Samonikov ${ }^{1}$, Mila Mitreva², Elena Veselinova ${ }^{3}$, Ljupco Davcev ${ }^{4}$}

${ }^{1}$ Goce Delcev University, Faculty of Economics, Krste Misirkov St., 10-A, Republic of Macedonia, e-mail: marija.gogova@ugd.edu.mk

${ }^{2}$ Goce Delcev University, Faculty of Economics, Krste Misirkov St., 10-A, Republic of Macedonia,e-mail:mila.mitreva@ugd.edu.mk

${ }^{3}$ Goce Delcev University, Faculty of Economics, Krste Misirkov St., 10-A, Republic of Macedonia, e-mail: elena.veselinova@ugd.edu.mk

${ }^{4}$ Goce Delcev University, Faculty of Economics, Krste Misirkov St., 10-A, Republic of Macedonia, e-mail: Ijupco.davcev@ugd.edu.mk

\section{Abstract}

The Covid- 19 crisis has gripped the world as a whole, with all its subsystems. For some it was and still is a nightmare, for others an unprecedented opportunity. While some industries are getting poorer, other industries are getting richer. This paper covers the analysis of a sector to which this period is not so dark. It is about electronic banking. The need to maintain physical distance has intensified the use of e-banking in some countries even unforeseen. On the other hand, there is still a reluctance to use this way of using banking conditions, sometimes due to aversion to technology, sometimes due to ignorance.

This paper is written on the basis of a survey conducted among young people in the city of Stip, Macedonia, for their knowledge of banking and their predictions for electronic banking. A total of 202 people were interviewed and their answers were interpreted based on statistical analysis.

The conclusion of this paper should be based on the views of young people on electronic banking and its future. Based on them, a forecast should be given for the future trends of electronic banking in Macedonia's economic recovery. Methods of analysis, comparisons and statistical calculations were used to show the real picture of the current situation.

\section{Keywords}


COVID -19, E-banking, young people.

\section{Introduction}

Some surveys shows that almost $20 \%$ of all retail banking customers have used at least one online service for the first time during the crisis, and just $6 \%$ have made no use of them at all. Moreover most first-time users say that they want to continue to use at least some online services once the crisis has passed, although the 'conversion rate' will differ between services. Retail banks now have an opportunity to win over customers to the benefits of online banking, but they will need a convincing multi-faceted approach that includes hybrid solutions - particularly for complex bank services, such as mortgages and investments - if they are to persuade customers across the board.

\section{E - banking in the world and its application versus the situation in Macedonia - during the crisis}

Banks play crucial role in the worldwide economy, because of their main role to serve as safe haven for depositors and as a credit-providing source for households, business entities and governments. Despite transforming the illiquid assets to liquid liabilities, they also manage the interest rates, foreign exchange rates, solvency and various other off-balance sheet activities. Therefore, innovative societies, entrepreneurial businesses and economic growth could not be stimulated without the financial services providers [4]. The existing theory, such as the papers of King and Levine (1993), Demirguc-Kunt and Maksimovic [8], Berger et al. [3] and Christopoulos and Tsionas [6]) show that financial development stimulates economic growth. In this so-called finance-growth nexus, banks have very important part. Undoubtedly, the interconnection between banks and the real economy is very strong. However, this interconnection is especially evident during a period of a crisis and economic stress. Usually, the financial and the economic crises are not exogenous to the banking industry, which makes it difficult to provide simplified and precise conclusion how these kind of crises affect the banks. Considering that during recessions the demand for financial services is reduced, it is nonnegotiable that financial institutions, such as the banks can have negative effect on the real economy. Nevertheless, in every crisis, only the most flexible businesses manage to maintain their day-to-day operations. The corona pandemic reshaped the way many industries used to function. The new, digitalized world did not leave the financial industry untouched. Hence, online services have become very important component of retail banking, which contributed to an increase in the banks' account logins, remote deposits and online account openings [13]. Furthermore, online applications for business loans have shown to be very attractive for the consumers, while the mortgages, securities investments and payment transactions because of their complexity were least preferred by customers to be conducted online. Nevertheless, the consumer preferences and the pandemic have pressured the banks around the world to provide new and strengthen the existing digitalized services.

Moreover, the impact of the corona pandemic on the financial industry is a topic of great importance, because the outcome is changed consumer behavior in the retail banking. The effect from the crisis on the banking sector has contributed to an increased usage of digital channels and payments. Nevertheless, the digitalization of many of the banking services also has a negative side, such as operational resilience and an increased non-performing loans. [1]. According to Pop [12] the mostly impacted banking dimension during the current crisis 
are the channels of distribution, because of the changed customer buying preferences. Hoe (2020) in his paper shows that the limited physical contact and the usage of cash increased the digital banking registration in South-East Asia, Malaysia and UK. Buehler et al. [5] in their study refer to the importance of "positive and safety oriented messaging" in order banks to decrease their reliance on physical locations. Through these activities, banks will manage to embrace digital services, they will simplify the online transactions and will assist customers to adjust faster to the new reality. A good example of a bank that trained their customers to use digital channels is the Singapore DBS bank. However, the new circumstances may be advantageous for the young people and those who have digital experience. The imposed question is how the elderly, retired and unbanked consumers will adjust to this. The shift towards digital payments has not been easy for the countries which were more physicallypayment oriented. Such countries were South Korea and Hungary, where the central banks have claimed that coronavirus transmission through banknotes is very low. However, some countries, like Scandinavian, which already had cashless societies, did not perceive the whole situation as a shock, while others, like India and Indonesia were eager to adapt fast and have encouraged the people to switch towards cashless payments [1]. Therefore, McCarty [10] in his paper calls for flexible approaches and highlights the importance of chat channels for banks' customers. It is worth mentioning that all these adjustments are not only for short-term and for the period until the pandemic is over. All these changes will have a long-term impact on the banks and the way in which they used to operate will be in the past. Hence, partnerships with finetechs was one of the topics discussed on the World Economic Forum in 2020, and an area which was analyzed in the paper of Melamedov [11], where it is stated that this innovative solutions will assist the banks to introduce new products. Not only new and innovative partnerships, but also mergers within and outside the financial industry will be of key importance for the banks after the pandemic is over [1].

Notwithstanding, since the occurrence of Covid-19, almost every bank around the world has shown its potential to quickly adjust, respond rapidly, act boldly and implement innovative solutions. Central banks have intervened by using all the possible measures that they have in order to calm the markets and show commitment to their customers. Some banks, such as BoJ (Bank of Japan) have increased the asset purchases in order to maintain the liquidity in the market. Same was done by the People's Bank of China (PBOC) and the US Federal Reserve [2]. All these measures created revolutionization in the banking industry, but how the customers have responded is not exception as well. Most of them have used online banking for the first time since the occurrence of the crisis. In an analysis conducted by Deloitte, $16 \%$ of the respondents who have used online services for the first time during the pandemic have taken out consumer loan electronically, $15 \%$ took out a mortgage, $14 \%$ conducted securities investment, $13 \%$ used and information on a bank service, while $15 \%$ required advice on a bank service. With the pandemic, the existing online trends were much more accelerated, and most of the people are planning to continue using the online services [7]. Considering the situation globally, Macedonia was not an exception. The banking sector in Macedonia managed to adjust quickly, having in mind that every bank already was providing online services. However, the people were more oriented towards the traditional way of working with the banks and they did not fully accepted the possibility of abandoning the branches. Nevertheless, the e-commerce banking growth experienced an increase, due to the products, which were already created for e-banking purposes. 


\section{The perception of banking by young people in Macedonia}

In accordance with the topic of obtaining information on the situation with the perception of young people about banking in Macedonia, we conducted two surveys. The purpose of the research was young people, in one group of people aged 18 to 27 years, and in the second group of people aged 16 to 18 years. We have singled out the second group of people in a special category because they are high school students and people who have essentially limited access to financial systems on the one hand, but on the other hand are on the verge of coming of age and participating in financial systems. We should not forget the fact that these are the categories of people who most often use electronic devices, are usually not averse to new technologies and on the other hand with a careful approach can easily implement the innovations implemented by banking institutions.

The first survey included a survey of 133 young people aged 18 to $27.74 .2 \%$ of them are female and $25.8 \%$ male.

Due to the fact that education has a role in shaping the perception, the question was asked how many of them have economic education, which resulted in $56.3 \%$ having economic education, and the remaining $43.8 \%$ without economic education. With this we get an almost absolutely divided environment in terms of education and knowledge of economic terms and aspects.

Of the respondents, $94.7 \%$ are students and $87.6 \%$ are employees. It is interesting to note that $7.7 \%$ of people do not know what commercial banks are, while $58.5 \%$ know the meaning of this term. The remaining $33.8 \%$ stated partial knowledge of what commercial banks are. Despite the answer of a good part of them that they do not know what the term commercial bank is, they stated that they know such institutions (85.9\%), while $12.9 \%$ always use these institutions, $43.9 \%$ often use them, $27.3 \%$ use them sometimes, 13.6 rarely and $2.3 \%$ never. The most common use of this institution is for payment of bills and activities related to payment operations, and the following are listed for taking loans, investing funds and exchange operations.

Unlike classical banking, as many as $70.5 \%$ said they knew what electronic banking was, and $50.8 \%$ said they knew what mobile banking was. From the aspect of knowledge of mobile banking, there are variations in the possibilities for probable knowledge of this term and $18.9 \%$ stated that they probably know the meaning of the term, $15.9 \%$ that they may know the term, while $10.6 \%$ do not know what mobile banking is. $64.4 \%$ of the respondents differentiate between electronic and mobile banking.

Absolute confidence in the electronic banking was stated by $28.2 \%$, the next rank in the series of 5 gradations is $32.8 \%$, then $19.1 \%, 14.5 \%$ and general confidence in this operating system by $5.3 \%$. Contrary to the trust, $47.7 \%$ prefer electronic banking, $37.9 \%$ partially, and the remaining $14.4 \%$ do not prefer electronic banking. To the question: For which form of electronic banking are you most sure that it was performed without room for error? - $80.8 \%$ stated that it is for payment / collection of bills.

Young people, respondents, almost absolutely agree that banking is a positive phenomenon. $46.2 \%$ agree and $40.2 \%$ partially agree (which would be $86.4 \%$ in total). The remaining 
$13.7 \%$ have a neutral attitude. Depending on the service, $53.4 \%$ rate it as cheaper, ie $42 \%$ absolutely consider it as a cheaper form of banking.

The second survey included 89 young people surveyed aged 15 to 19 (third and fourth year high school students). $64.4 \%$ of them are female and $35.6 \%$ male.

This surveyed group is characterized by much lower economic education, ie $65.5 \%$ stated that they have no form of economic education, and $34.5 \%$ that they have some form of economic education. However, unlike the respondents in the first survey, these stated that they have partial knowledge of what the term commercial bank is (45.4\%), $35.2 \%$ have complete knowledge, while $19.3 \%$ are uninformed. $75 \%$ can list such an institution in Macedonia, but still rarely use its services (which is logical given that these are minors). When they used a bank service, the largest percentage (80.5\%) was for payment of bills.

The fact that $48.9 \%$ know what electronic banking is, is quite optimistic, and if we add to this $22.7 \%$ who assessed that they probably know what this term is, we get a satisfactory $71.6 \%$. Such concentrated statistics are not obtained when asked if they know what mobile banking is. The 5 member gradation is represented here with the following percentages: $31.8 \%$, $12.5 \%, 31.8 \%, 13.6 \%$ and $10.2 \%$.

Again, the fact that $54 \%$ of respondents distinguish between electronic and mobile banking is optimistic. They are cautious when it comes to electronic banking, but still prefer electronic banking, usually for payment / collection of bills.

\section{Future expectations for E-banking}

The expectations of the young people from the first examined group for the electronic banking operation are primarily based on how much it has been used. The survey showed that $17.4 \%$ always use this form of banking, $37.1 \%$ often, $34.1 \%$ rarely, $11.4 \%$ never. Easier access, cheaper services, greater information, greater security in e-commerce influence their decision to use, partially use and not use.

Young people's perception of whether the pandemic changed the banking business is confirmed by $35.4 \%, 40 \%$ partially agree, and the remaining $24.6 \%$ think that the pandemic had no share in banking (especially electronic banking).

Young people cite the following changes that are taking place in the field of e-banking: increasing the use of digital services, reducing bank congestion, improving virus protection, conducting transactions and home payments, increasing the propaganda activities of commercial banks to direct customers to electronic banking.

To the question: Do you think that electronic banking has a future and can replace the classic banking? - The largest percentage of respondents (46.2\%) expressed partial consent, $27.3 \%$ had a neutral position, and $15.9 \%$ expressed complete agreement.

In the sub-domain of electronic banking, mobile banking is used by $61.4 \%$, and $38.6 \%$ do not use such services. 
In order to get a more realistic picture of the situation with the views of young people about ebanking, it was necessary to ask whether the respondents own a personal computer, to which we received the answer that $90.1 \%$ have their own computer, $78 \%$ have access to unlimited internet, which percentage increases if we take into account that the next $17.4 \%$ often have access to the Internet, the percentage would be $95.4 \%$. These high numbers indicate that young people in Macedonia are not technically restricted from using e-banking. Even they themselves stated that the Internet is rarely the problem for using e-banking services (56.5\%).

Age is also a key aspect that has a share in the level of transactions made through electronic banking (by $56.5 \%$ ), while for $33.6 \%$ age has a share, but depending on the type of service.

From the aspect of education, $41.5 \%$ agree that education affects the level of transactions performed through electronic banking, and $50 \%$ think that additional education for electronic banking is needed. For $49.4 \%$ of the respondents the additional education should be in the form of more frequent promotion, for $41.4 \%$ flyers are needed, for $36.8 \%$ courses, for $27.6 \%$ formal education is needed. Young people see the way to bring e-banking closer to the citizens through: increasing security and information, bigger and more frequent, promotion, websites for a detailed explanation of the procedures for electronic banking.

Speaking of the future of banking, $60 \%$ of respondents said they would not use another institution for the services provided by banks, such as exchange offices, savings banks, post offices or fast loans, and if they use such an institution, it would usually be the post office, because there the commissions are lower and the exchange offices when it comes to currency conversion.

In this regard, in the view of the young people on the future of electronic banking compared to other financial institutions, we came to the following data.

To the question: Would you rather deposit your funds or invest them in another form of investment such as stocks, insurance, pension funds? - 69.8\% stated that it depends on the current situation, $17.8 \%$ that they would invest them in another form (mostly in shares), and $12.4 \%$ that they would deposit.

Finally, we can conclude that young people from banks rarely have an unpleasant experience, even it comes down to almost never. They do not have a definite position on whether Macedonian banks are competitive and the majority (53.8\%) think that banks offer real prices for products and services.

The surveys of young people from the second surveyed group in the largest percentage of $37.5 \%$ agree that e-banking is a positive phenomenon and if we add to them $31.8 \%$ who partially agree we can conclude that their perceptions of the future of e-banking are positive. These respondents, like the previous group, think that depending on the service the price of bank offers will vary.

Easier access is rated (by 79.3\%) as the most important factor influencing to convince a young person to use this type of services. Other listed factors are higher information, of $36.8 \%$, cheaper services of $29.9 \%$ and higher level of security in electronic transactions of $24.1 \%$ 
According to this group of respondents, $51.1 \%$ stated that the pandemic partially causes changes in the banking operations in the direction of payments and shopping from home, increasing the volume of electronic transactions, increasing lending. However, the view on whether e-banking will replace the classic one is divided into categories that completely agree, partially agree, but also on a neutral position.

This group of respondents are persons who own a personal computer (96.6\%) and have access to unlimited internet (94.4\%) and accordingly do not consider the Internet as a problem for electronic banking. Half of the respondents consider age as a factor influencing this type of banking, and a slightly lower percentage (43.2\%) consider education as a key factor in using electronic banking services. $68.2 \%$ think that additional education is needed on this topic and they think the courses, more frequent promotion, formal education and finally the flyers are the most effective. They have listed these same channels as their example of a means that would effectively prepare citizens for the transition to this type of banking.

$69 \%$ of the respondents would not use the services of institutions such as exchange offices, quick loans, savings banks and post offices, and the remaining $31 \%$ would use the services of other institutions mostly because of cheaper interest rates and quick and easy access offered by alternatives.

This group of respondents is more skeptical about the level of prices in the banking institutions and most of them stated that sometimes banks offer real prices for their offers.

\section{Conclusions}

This paper indicates that current world developments are causing changes in the financial sector. One of those changes is the actualization of electronic banking. This form of banking has gained momentum in our republic as well. Although, there are still aspects that block the use of e-banking such as the fear of mistakes, rejection of technological inventions, fear of irreversible virus consequences, a sense of educational emptiness, adult degradation, young people are aware of them and are on the right track to eliminate them.

When it comes to young people, even those who are on the verge of officially stepping into the social financial system, there is a willingness and interest to use electronic banking. Young people also believe that there should be an additional form of education (formal or not) that will facilitate and encourage the inclusion of this type of financial work. This operation is certainly assessed as cheaper, but Macedonia was imposed as a consequence of the measure for keeping distance and a limited number of clients in a branch. The intensification of the use of electronic banking in Macedonia by the general public did not appear as awareness and development of the society, accompanied by trust, but as a result of the Covid crisis.

However, the road has begun and the perceptions of young people who are moving towards accepting this system indicate a good probability of hope that the process of electronic financial operations will only go up. 


\section{References}

1 Baicu, C. G, et al. (2020) The impact of Covid-19 on consumer behavior in retail banking. Evidence from Romania. Management and Marketing. Challenges for the Knowledge Society. Vol. 15, No. Special Issue, p. 534-556.

2 Baret, S., et al. (2020) Covid-19 potential implications for the banking and capital markets sector. Deloitte insights. Retrieved from:

https://www2.deloitte.com/content/dam/insights/us/articles/6693 covid-19-banking/DI COVID-19banking.pdf

3 Berger, A. N., et al. (2004) Further evidence on the link between finance and growth: an international analysis of community banking and economic performance. Journal of Financial Services Research.

Vol. 25, p. 169-202.

4 Berger, A. N., et al. (2020) Banks and the real economy: An assessment of the research. Journal of corporate Finance. Vol. 62. Retrieved from:

https://www.sciencedirect.com/science/article/abs/pii/S0929119919307813?via\%3Dihub [Accessed 1 $1^{\text {st }}$ September 2021].

5 Buehler, K., et al. (2020) Leadership in the time of coronavirus: COVID-19 response and implications for banks. McKinesy\&Company. Retrieved from

https://www.mckinsey.com/industries/financial-services/our-insights/leadershipin-the-time-ofcoronavirus-covid-19-response-and-implications-for-banks

6 Christopoulos, D. K. and Tsionas, E. G. (2004) Financial development and economic growth:

evidence from panel unit root and cointegration tests. Journal of Development Economics. Vol. 73, No. 1 , p. 55-74.

7 Deloitte website (2020) Digitalisation of banking: will the move to online banking continue after the Covid-19 pandemic? Deloitte website. Retrieved from:

https://www2.deloitte.com/ch/en/pages/financial-services/articles/digitalisation-banking-online-covid19-pandemic.html

8 Demirguc-Kunt, A. and Maksimovic, V. (2002) Law, Finance and Firm Growth. The Journal of Finance. Vol. 53, No. 6, p. 2107-2137.

9 Hoe, L.K. (2020) COVID-19: opportunities and challenges for digital banks. PWC Malaysia.

Retrieved from https://www.pwc.com/my/en/perspective/

10 McCarty, B. (2020). Managing customer relationships in the time of COVID-19, BAI. Banking

Strategies. Retrieved from https://www.bai.org/banking-strategies/articledetail/managing-customer-

relationships-in-the-time-of-covid-19

11 Melamedov, L. (2020). Coronavirus (COVID-19) and the banking industry: impact and solutions, Lightico, Retrieved from https://www.lightico.com/blog/coronaviruscovid-19-and-the-banking-industryimpact-and-solutions/

12 Pop, N. A. (2020) Contemporary Directions in the Development of Romanian Academic Marketing in Favor of Increasing the Performance of the Organization. Challenges and Opportunities to Develop Organizations Through Creativity, Technology and Ethics. GSMAC 2019. Springer Proceedings in Business and Economics. Springer, p. 17-35.

13 Sheng, E. (2020) Coronavirus crisis mobile banking surge is shift that's likely to stick. CNBC website. Retrieved from: https://www.cnbc.com/2020/05/27/coronavirus-crisis-mobile-banking-surgeis-a-shift-likely-to-stick.html 